\title{
UJI KINERJA ELEKTROLIZER HHO MENGGUNAKAN SEL SURYA SEBAGAI SUMBER DAYA DC
}

\author{
Sapto Praygo ${ }^{1}$, Hartono Budi Santoso ${ }^{2}$ \\ Jurusan Teknik Konversi Energi - Politeknik Negeri Bandung \\ Email: ${ }^{1)}$ saptoprajogo@gmail.com, ${ }^{2)}$ hartono@esi-labs.com
}

\begin{abstract}
Abstrak
Gas $H H O$ atau disebut brown gas merupakan campuran gas hidrogen dan oksigen yang buat dengan proses elektrolisis larutan air. Secara umum, elektrolisis air menghasilkan gas hidrogen di katoda dan oksigen di anoda.Gas HHO ini merupakan "gas air" yang mana gas hidrogen dan gas oksigen tercampur.

Elektrolisis merupakan reaksi kimia yang yang terjadi karena adanya energi listrik yang dialirkan dalam larutan elektrolit. Sel surya dapat dimanfaatkan sebagai alternatif sumber energi listrik pada proses elektrolisis untuk dapat menghasilkan gas $\mathrm{HHO}$.

Pada penelitian ini dilakukan kajian tentang uji kinerja elektroliser gas HHO menggunakan sel surya sebagai sumber daya $D C$ terhadap produksi gas $H H O$. Hasil pengujian menunjukan rata-rata produksi gas $H H O$ menggunakan solar panel $200 \mathrm{Wp}$ pada rata-rata fluk radiasi sebesar 478,86 W/m2 dihasilkan $862,73 \mathrm{ml}$ dengan waktu yang dibutuhkan selama hampir 4 menit
\end{abstract}

Kata kunci: elektroliser, gas $H H O, L P G$, sel surya.

\section{PENDAHULUAN}

Gas HHO atau disebut brown gas merupakan campuran gas hidrogen dan oksigen yang buat dengan proses elektrolisis larutan air. Secara umum, elektrolisis air menghasilkan gas hidrogen di katoda dan oksigen di anoda.Gas HHO ini merupakan "gas air" yang mana gas hidrogen dan gas oksigen tercampur. Karakteristik dari gas HHO diantarnya adalah:

1. Memiliki kandungan energi yang tinggi dan mampu menghasilkan nyala api dingin (cold flame) dengan potensial energi yang tinggi apabila dibakar.

2. Mempu menyalurkan energi ke sebuah material dalam bentuk struktur atom.

3. Mudah dikendalikan, tidak berbau dan tidak berbahaya terhadap tubuh manusia bahkan apabila terhirup sekalipun.

4. Dapat berdifusi dengan udara dengan cepat

Elektrolisis merupakan reaksi kimia yang yang terjadi karena adanya energi listrik yang dialirkan dalam larutan elektrolit. Pada Proses elektrolisa, molekul air dipisahkan menjadi gas hidrogen dan oksigen dengan cara mengalirkan arus listrik ke elektroda pada larutan elektrolit. Tegangan yang dibutuhkan pada elektrolisis untuk dapat menghasilkan $\mathrm{H}_{2}$ dan $\mathrm{O} 2$, lebih besar dari 1,7 Volt. Beberapa kajian terkait proses elektrolisis untuk menghasilkan gas $\mathrm{HHO}$ antara lain ;

- Kajian tentang pengaturan frekwensi sumber daya DC pada elektroliser menunjukan hasil yang menyatakan bahwa frekwensi untuk generator dengan effisiensi thermal terbaik adalah pada $10 \mathrm{~Hz}$ sebesar $20,06 \%$. Dengan daya generator 118,74 Watt, debit 13,13 L/jam [1].

- Bagaimana pengaruh variasi arus listrik terhadap produksi brown's gas pada elektroliser, menunjukan ada korelasi antara besarnya daya listrik yang digunakan terhadap produksi gas $\mathrm{HHO}$ yang dihasilkan [2].

- Studi tentang pengaruh Ketebalan Elektroda Pada Produksi Gas HHO (Hidrogen Hidrogen Oksigen) Oleh Generator Hho Tipe Basah Dengan Katalis $\mathrm{NaHCO} 3 \quad$ (Natrium Bikarbonat) memberikan hasil kajian yang menunjukan bahwa terdapat pengaruh yang besar antara perbedaan ketebalan elektroda pada generator HHO terhadap parameter yang digunakan yaitu daya yang digunakan, volume gas yang dihasilkan, laju produksi dan efisien si generator yang dihasilkan oleh masing-masing generator berdasarkan perbedaan ketebalan elektrodanya[3]. 
Aplikasi gas HHO salah satunya sebagai alternatif bahan bakar untuk kegiatan masak memasak, khususnya untuk daerah yang tidak tersedia bahan bakar minyak maupun gas, bahkan listrik. Untuk dapat menghasilkan gas $\mathrm{HHO}$ pada daerah yang tidak ada listrik maka sebagai alternatif sumber energi listrik dapat memanfaatkan panel surya.

Pada penelitian ini dilakukan kajian tentang uji kinerja elektroliser gas $\mathrm{HHO}$ menggunakan sel surya sebagai sumber daya DC terhadap produksi gas $\mathrm{HHO}$.

\section{METODE PENELITIAN}

\subsection{Generator HHO}

Generator $\mathrm{HHO}$ adalah alat dalam memproduksi gas HHO. Terdiri dari tabung/bejana yang tahan terhadap tekanan dan temperature tinggi, elektroda sebagai penyalur arus listrik, lubang pernafasan, dan lubang transfer gas $\mathrm{HHO}$.

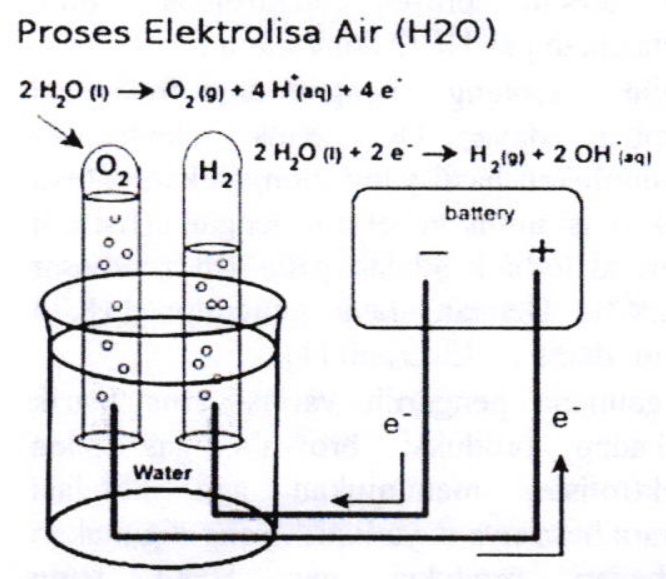

Gambar 1. Proses Elektrolisa

Tabung elektroda digunakan sebagai tempat menampung larutan elektrolit, sekaligus sebagai tempat terjadinya proses elektrolisis untuk menghasilkan gas HHO. Elektroda adalah kutub yang menjadi penghantar listrik. Elektroda yang baik adalah logam yang memiliki konduktifitas baik dan tahan korosi. Sedangkan elektrolit berfungsi memindahkan ion ion yang terlibat dalam reaksi reaksi reduksi dan oksidasi.

Ada dua jenis elektrolizer gas HHO yaitu wet cell dan dry cell. Pada tipe wet cell seluruh elektrodanya terendam air sementara pada tipe dry cell sebagian saja dari elektroda yang terendam air [4].

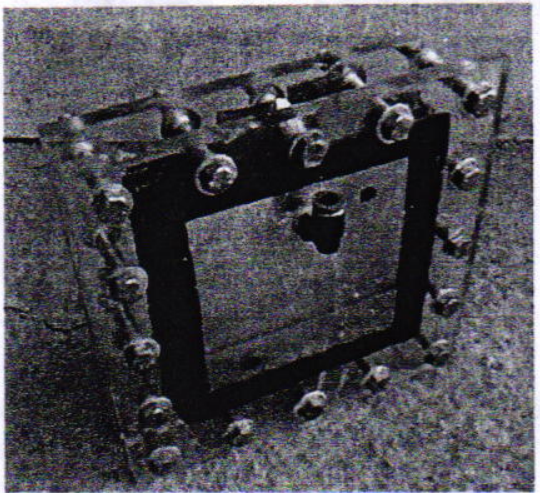

Gambar 2. elektrolizer dry cell

\subsection{Suplay DC Elektrolisis}

Produksi gas HHO berdasarkan kajian yang telah dilakukan dipengaruhi oleh daya listrik yang diberikan pada generator elektroliser. Beberapa perhitungan terkait besaran produksi gas HHO yang dihasilkan adalah sebagai berikut :

a. Daya yang dibutuhkan untuk proses produksi $\mathrm{HHO}$

Besarnya daya yang dibutuhkan generator HHO ditentukan oleh besarnya tegangan dan arus listrik yang digunakan dalam proses elektrolisis.Perhitungannya menggunakan Persamaan 1.

$\mathrm{P}=\mathrm{V} \times \mathrm{I}$

Dimana :

- $\mathrm{P}=$ Daya generator HHO (Watt)

- $\mathrm{V}=$ Beda potensial/tegangan (Volt)

- $\mathrm{I}=$ Arus listrik (Ampere)

b. Laju produksi /flow rate gas HHO.

Laju produksi gas $\mathrm{HHO}$ ditentukan dengan Persamaan 2.

$\dot{\mathrm{m}}=\mathrm{Q} \times \rho_{\mathrm{HHO}}$

Dimana :

- $\dot{\mathrm{m}}=$ Laju produksi gas $\mathrm{HHO}(\mathrm{kg} / \mathrm{s})$

- $\mathrm{Q}=$ Debit Produksi gas HHO (lt/s)

- $\rho=$ Massa jenis gas HHO (gram)

Dengan :

$\mathrm{Q}=\mathrm{v} / \mathrm{t}$

Dimana :

- $\mathbf{v}=$ Volume gas terukur (lt)

- $\mathrm{t}=$ Waktu produksi gas (s)

$\rho_{\text {HHO }}=0,287 \mathrm{gr} / \mathrm{L}$

$\rho_{\text {Hidrogen }}=0,069 \mathrm{gr} / \mathrm{L}$

$\rho_{\text {Oksigen }}=0,219 \mathrm{gr} / \mathrm{L}$ ) 
c. Efisiensi Generator HHO.

Efisiensi generator $\mathrm{HHO}$ atau proses elektrolisis dihitung dengan Persamaan 4.

$\eta_{\mathrm{HHO}}=\frac{\mathrm{Q}_{\mathrm{HHO}} \times \rho_{\mathrm{HHO}} \times \mathrm{LHV}_{\mathrm{HHO}}}{\mathrm{P}_{\mathrm{HHO}}} \times 100 \%$.

Dimana:

- $\eta_{\mathrm{HHO}}=$ Efisiensi generator $\mathrm{HHO}(\%)$

- $\mathrm{Q}_{\mathrm{HHO}}=$ Debit produksi gas $\mathrm{HHO}(\mathrm{lt} / \mathrm{s})$

- $\rho_{\text {HHO }}=$ Massa Jenis gas HHO (g/lt)

- $\mathrm{LHV}_{\mathrm{HHO}}=\mathrm{LHV}$ gas $\mathrm{HHO}(119930 \mathrm{~J} / \mathrm{g})$

- $\mathrm{P}_{\mathrm{HHO}}=$ Daya generator $\mathrm{HHO}$ (Watt)

\subsection{Sel Surya}

Sel surya adalah suatu perangkat dari bahan semikonduktor terdiri dari diode $\mathrm{p}-\mathrm{n}$ junction yang mampu mengubah radiasi matahari menjadi energi listrik. Energi foton akan mengeksitasi sebagian elektron pada suatu material ke pita energi yang lebih luar. Radiasi matahari akan mengeksitasi elektro dari ikatannya sehingga menjadi elektron bebas bergerak menuju potensial yang lebih tinggi. Ketika kedua ujung potensial dihubungkan dengan sebuah beban sehingga membentuk rangkaian tertutup maka akan terjadi aliran listrik. Hal ini yang terjadi ketika sel surya terkena radiasi matahari seperti dijelaskan pada gambar

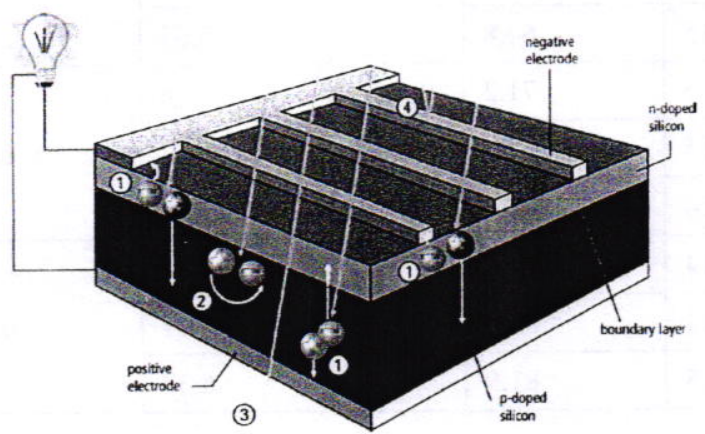

Gambar 3. Prinsip kerja sel surya

Berdasarkan material yang digunakan untuk membuat sel surya maka ada beberapa tipe sel surya antara lain [5] :

- Mono kristal

- Poli kristal

- Copper Indium Diselenide (CIS)

- Cadmium Telluride (CdTe)

- Amorphous silicon

Perbandingan dari masing-masing tipe sel surya terhadap kemampuan daya yang dihasilkan persatuan luas seperti tampak pada tabel berikut.
Tabel 1. Perbandingan luasan sel surya terhadap daya yang dihasilkan

$\begin{array}{lll}\text { Cell material } & \text { Required PV area for } 1 \mathrm{~kW}_{\mathrm{p}} \\ \text { Mono-crystalline } & 7 \mathrm{~m}^{2}-9 \mathrm{~m}^{2} \\ \text { High performance cells } & 6 \mathrm{~m}^{2}-7 \mathrm{~m}^{2} & \\ \text { Polycrystalline } & 7.5 \mathrm{~m}^{2}-10 \mathrm{~m}^{2} \\ \text { Copper indium diselenide (CIS) } & 9 \mathrm{~m}^{2}-11 \mathrm{~m}^{2} & \\ \text { Cadmium telluride (CdTe) } & 12 \mathrm{~m}^{2}-17 \mathrm{~m}^{2} & \\ \text { Amorphous silicon } & & \end{array}$

Pada aplikasinya sel surya akan dirangkai secara serial dan paralel membentuk satu panel surya dengan daya keluaran yang bervariasi sesuai dengan spesifikasi dari panel surya. Daya keluaran yang tertera pada panel surya didasarkan pada standar pengujian pada suhu $25^{\circ} \mathrm{C}$ dan radiasi sebesar $1000 \mathrm{~W} / \mathrm{m}^{2}$. Sehingga pada saat digunakan biasanya daya yang dihasilkan akan kurang dari spesifikasi yang tertulis pada panel karena radiasi yang diterima kurang dari $1000 \mathrm{~W} / \mathrm{m}^{2}$.

Daya listrik yang dihasilkan oleh sel surya dapat dihitung berdasarkan pengukuran arus dan tegangan keluaran dari panel surya, seperti ditunjukkan pada persamaan 5. Daya total yang dihasilkan dari pemanfaatan beberapa panel surya yang dirangkai baik secara seri ataupu paralel dapat dihitung menggunakan persamaan 6 .

$\mathrm{P}_{\text {panel }}=\mathrm{VI}$

dengan:

$\mathrm{P}_{\text {panel }}=$ Daya keluaran (Watt)

$\mathrm{V}=$ Tegangan keluaran (Volt)

I $=$ Arus (Ampere)

$\mathrm{P}_{\text {total }}=\mathrm{P}_{\text {panel }} \times \mathrm{N}$

dengan:

$P_{\text {total }}=$ Daya total (Watt)

$P_{\text {panel }}=$ Daya keluaran per Panel

$N \quad=$ jumlah panel

\subsection{Metode Pengujian}

Pada penelitian ini akan dilakukan pengukuran produksi gas $\mathrm{HHO}$ terhadap daya masukan DC. Sumber DC yang digunakan bersumber dari sel surya yang akan menghasilkan daya listrik sesuai dengan radiasi matahari. 


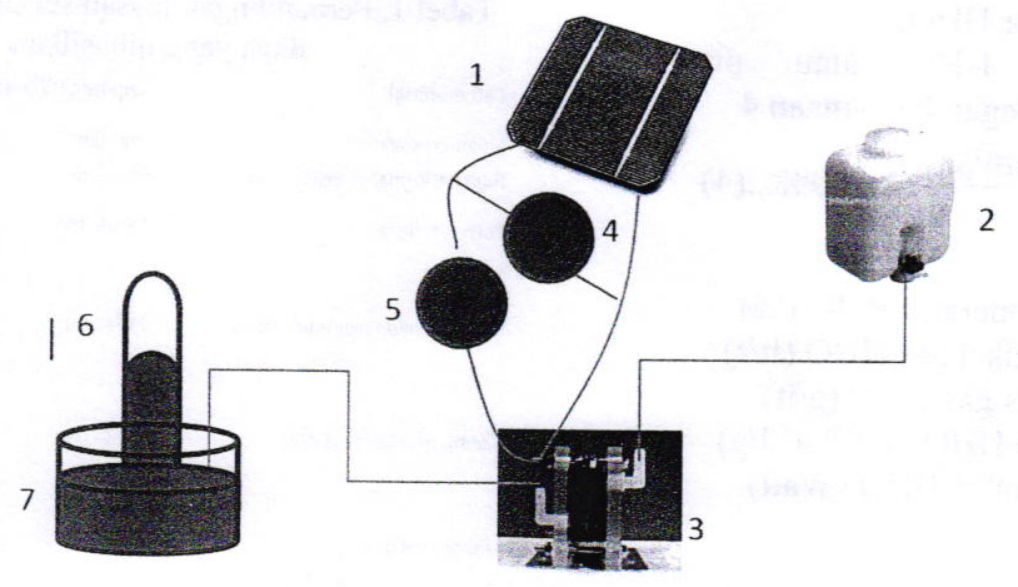

Keterangan :

Gambar 4. Skema pengujian Kompor LPG dengan penambahan gas HHO

1. Sel surya

2. Water tank

3. Elektroliser

4. Voltmeter
5. Amperemeter

6. Gelas ukur

7. Ember

Tabel 2. Data Produksi gas HHO terhadap konsentrasi KOH

\begin{tabular}{|c|c|c|c|c|c|c|c|c|c|c|}
\hline \multirow{2}{*}{$\mathrm{m}_{\mathrm{KOH}}(\mathrm{g})$} & \multirow{2}{*}{$V($ volt $)$} & \multirow{2}{*}{ I (amps) } & \multicolumn{2}{|c|}{$\mathrm{v}(\mathrm{ml})$} & \multirow{2}{*}{$\begin{array}{c}\Delta \mathrm{v} / \mathrm{v}_{\text {HHO }} \\
(\mathrm{ml})\end{array}$} & \multirow{2}{*}{$t(s)$} & \multirow{2}{*}{$P(W)$} & \multirow[b]{2}{*}{$\mathrm{P}(\mathrm{W})$} & \multirow[b]{2}{*}{$\mathrm{Q}(\mathrm{ml} / \mathrm{s})$} & \multirow[b]{2}{*}{$\bar{Q}(\mathrm{ml} / \mathrm{s})$} \\
\hline & & & awal & akhir & & & & & & \\
\hline 5 & 9 & 6.8 & 290 & 370 & 80 & 15 & 61.2 & \multirow{3}{*}{63.9} & 5.33 & \multirow{3}{*}{5.67} \\
\hline 5 & 9 & 7.3 & 285 & 375 & 90 & 15 & 65.7 & & 6 & \\
\hline 5 & 9 & 7.2 & 320 & 405 & 85 & 15 & 64.8 & & 5.67 & \\
\hline 10 & 8.9 & 8 & 315 & 405 & 90 & 15 & 71.2 & \multirow{3}{*}{71.82} & 6 & \multirow{3}{*}{6.38} \\
\hline 10 & 8.9 & 8.3 & 315 & 415 & 100 & 15 & 73.87 & & 6.67 & \\
\hline 10 & 8.8 & 8 & 310 & 440 & 130 & 20 & 70.4 & & 6.5 & \\
\hline 15 & 8.2 & 9 & 395 & 510 & 115 & 14 & 73.8 & \multirow{3}{*}{79.8} & 8.21 & \multirow{3}{*}{6.87} \\
\hline 15 & 9 & 9.3 & 255 & 340 & 85 & 14 & 83.7 & & 6.07 & \\
\hline 15 & 9 & 9.1 & 245 & 340 & 95 & 15 & 81.9 & & 6.33 & \\
\hline
\end{tabular}

Produksi gas $\mathrm{HHO}$ juga ditentukan oleh konsentrasi katalis yang digunakan, dalam percobaan ini digunakan $\mathrm{KOH}$, sehingga akan dilakukan pengujian produksi gas $\mathrm{HHO}$ terhadap konsentrasi $\mathrm{KOH}$.

Untuk mendapatkan gambaran antara besarnya produksi gas $\mathrm{HHO}$ terhadap daya listrik masukan, maka dilakukan juga pengujian dengan menggunakan suplai DC, hal ini dilakukan karena pengukuran menggunakan sel surya tidak dapat diperoleh kondisi yang pasti, dikarenakan radiasi matahari yang berubah-ubah setiap saat. Skema pengujian seperti tampak pada gambar 4 .

\section{HASIL DAN PEMBAHASAN}

\section{Pengujianproduksi Gas HHO terhadap} konsentrasi KOH

Hasil pengujian seperti tampak pada tabel 2, semakin banyak massa $\mathrm{KOH}$ maka semakin besar pula produksi gas HHO. Produksi terbesar gas $\mathrm{HHO}$ ketika massa $\mathrm{KOH}$ 15 gram dan produksi gas $\mathrm{HHO}$ terkecil adalah ketika massa $\mathrm{KOH} 5$ gram. Hal tersebut terjadi karena ketika $\mathrm{KOH}$ semakin banyak, yang artinya konsentrasi elektrolit semakin pekat, maka kemampuan daya hantar arus pun semakin besar sehingga daya input pun semakin besar. Ketika daya input elektroliser 
semakin besar maka produksi gas HHO pun meningkat. Hal tersebut dapat dijelaskan dengan persamaan $V=I . R$, dengan $R=V /$, maka diketahui daya hantar listrik adalah $1 / R$, dengan nilai sebagai berikut:

Tabel 3. Pengaruh Massa KOH terhadap Resistansi dan Daya Hantar Listrik

\begin{tabular}{|c|c|c|c|}
\hline $\begin{array}{c}\text { Massa KOH } \\
\text { (gram) }\end{array}$ & $\mathrm{R}(\Omega)$ & $\mathrm{R}(\Omega)$ & $\mathrm{L}(\mho)$ \\
\hline 5 & 1.32 & \multirow{3}{*}{1.27} & \multirow{3}{*}{0.79} \\
\hline 5 & 1.23 & & \\
\hline 5 & 1.25 & & \\
\hline 10 & 1.11 & \multirow{3}{*}{1.09} & \multirow{3}{*}{0.91} \\
\hline 10 & 1.07 & & \\
\hline 10 & 1.1 & & \\
\hline 15 & 0.91 & \multirow{3}{*}{0.96} & \multirow{3}{*}{1.05} \\
\hline 15 & 0.97 & & \\
\hline 15 & 0.99 & & \\
\hline
\end{tabular}

Semakin besar nilai daya hantar listrik itu artinya daya yang dihantarkan oleh elektrolit semakin besar. Dapat dilihat bahwa semakin besar massa $\mathrm{KOH}$ maka semakin besar pula daya input elektroliser. Ketika massa $\mathrm{KOH} 5$ gram, daya input elektroliser hanya $63,9 \mathrm{~W}$ dengan daya hantar listrik 0,78 . Dan pada saat massa KOH 10 gram, daya inputnya naik menjadi $71,82 \mathrm{~W}$ dengan daya hantar listrik $0,91 \quad \mho$. puncaknya pada saat massa $\mathrm{KOH} 15$ gram, daya input naik menjadi $79,8 \mathrm{~W}$ dengan daya hantar listrik $1,046 \mho$.

\section{Pengujian produksi Gas HHO Dalam Sehari Menggunakan Sel Surya}

Hasil pengujian produksi gas $\mathrm{HHO}$ menggunakan sel surya $200 \mathrm{Wp}$ sebagai sumber listrik DC,dalam waktu 5038 detik elektroliser mampu menghasilkan 18980 $\mathrm{ml}$ HHO dengan fluks radiasi rata-rata 479 $\mathrm{W} / \mathrm{m}^{2}$.

Seperti tampak pada grafik gambar 5 . tampak produksi gas $\mathrm{HHO}$ meningkat ketika radiasi matahari tinggi, saat radiasi matahari turun gas yang dihasilkan berkurang dan waktu yang dibutuhkan juga semakin lama. Jika dirata-rata, hasil pengujian menunjukan rata-rata produksi gas $\mathrm{HHO}$ menggunakan solar panel $200 \mathrm{Wp}$ pada rata-rata fluks radiasi sebesar $478,86 \mathrm{~W} / \mathrm{m} 2$ dihasilkan $862,73 \mathrm{ml}$ gas HHO dengan waktu yang dibutuhkan selama hampir 230 detik atau sekitar 4 menit kurang 10 detik.

Dengan demikian jika asumsi cahaya matahari menyinari bumi dengan keadaan fluks radiasi konstan adalah dari pukul 10.00-14.00. Hal tersebut berarti waktu selama fluks radiasi konstan adalah selama 5 jam atau 18000 detik.

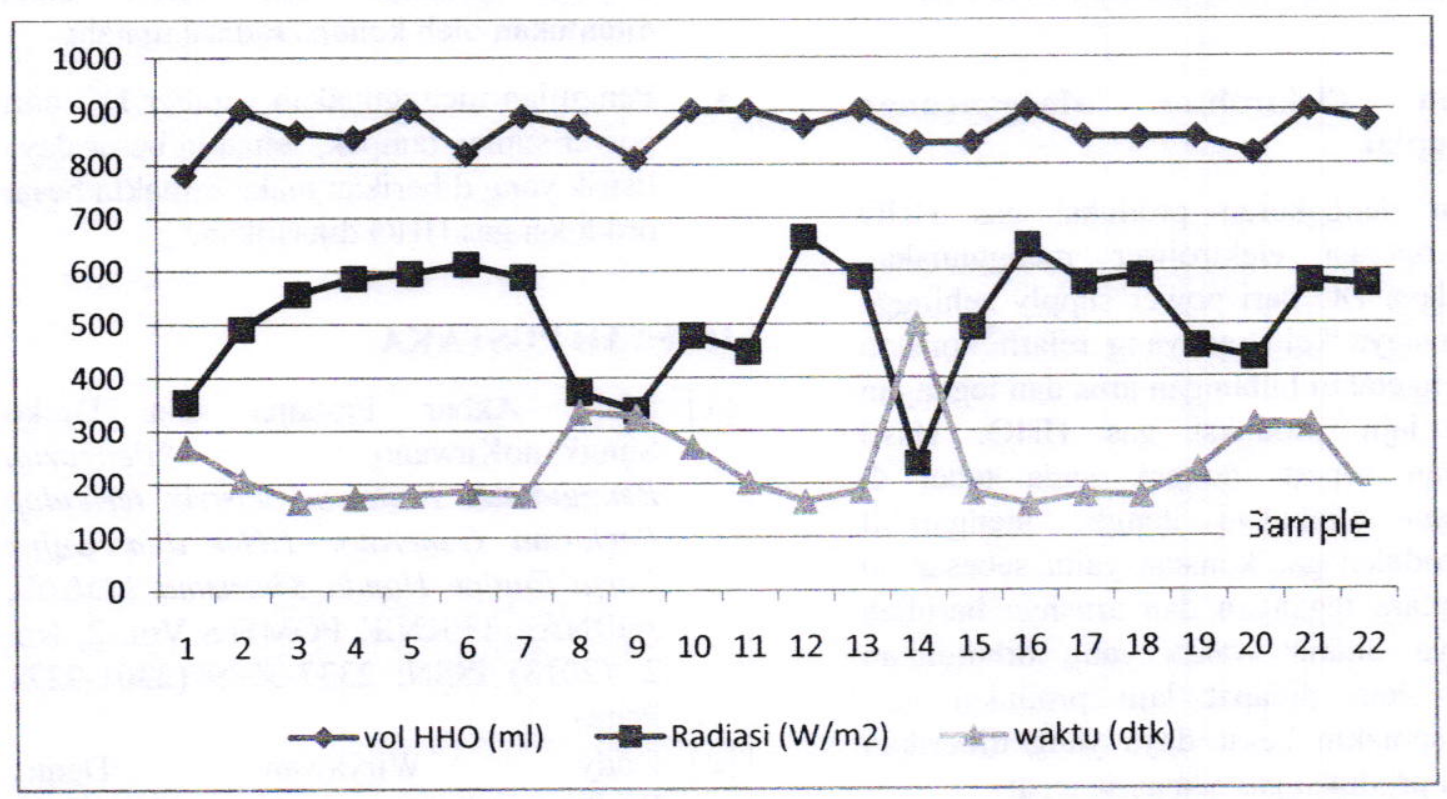

Gambar 5. Produksi Gas HHO menggunakan sel surya sebagai sumber DC 
Tabel 4. Percobaan Menggunakan Power Suplai

\begin{tabular}{|c|c|c|c|c|c|c|c|}
\hline $\mathrm{v0}(\mathrm{ml})$ & vl (ml) & $\Delta \mathbf{v}(\mathrm{ml})$ & $V($ volt $)$ & I (ampere) & $t(s)$ & $\overline{\mathrm{Q}}(\mathrm{ml} / \mathrm{s})$ & $\mathrm{v} / \mathrm{hari}(\mathrm{ml})$ \\
\hline 100 & 150 & 50 & 7,5 & 3,25 & 23 & \multirow{3}{*}{2,17} & \multirow{3}{*}{39060} \\
\hline 200 & 250 & 50 & 7,5 & 3,25 & 23 & & \\
\hline 300 & 350 & 50 & 7,5 & 3,25 & 23 & & \\
\hline 150 & 200 & 50 & 7,1 & 3,15 & 26 & \multirow{3}{*}{1,94} & \multirow{3}{*}{35064} \\
\hline 250 & 300 & 50 & 7,2 & 3,15 & 26 & & \\
\hline 350 & 400 & 50 & 7,2 & 3,15 & 25 & & \\
\hline 250 & 300 & 50 & 6,8 & 2,5 & 32 & \multirow{3}{*}{1,56} & \multirow{3}{*}{28125} \\
\hline 350 & 400 & 50 & 6,8 & 2,5 & 33 & & \\
\hline 50 & 100 & 50 & 6,8 & 2,5 & 31 & & \\
\hline 150 & 200 & 50 & 6,5 & 2,4 & 32 & \multirow{3}{*}{1,5} & \multirow{3}{*}{27000} \\
\hline 250 & 300 & 50 & 6,5 & 2,4 & 33 & & \\
\hline 350 & 400 & 50 & 6,5 & 2,4 & 35 & & \\
\hline
\end{tabular}

Maka, produksi gas $\mathrm{HHO}$ selama sehari adalah:

$$
\begin{aligned}
\text { Produksi HHO } & =\frac{18000 \times 18980}{5038} \\
& =67812,62 \mathrm{ml}
\end{aligned}
$$

Jadi, produksi gas HHO dalam sehari ketika cuaca sedang cerah berawan dengan irradiasi rata-rata $479 \mathrm{~W} / \mathrm{m}^{2}$ adalah kurang lebih $67812,62 \mathrm{ml}$ atau $67,81 \mathrm{~L}$.

\section{Pengujian Elektroliser Menggunakan Power Suplai}

Pengujian pengukuran produksi gas $\mathrm{HHO}$ dengan operasi elektroliser menggunakan sumber daya DC dari power supply sehingga diperoleh daya keluaran yang relatif konstan untuk mengetahui hubungan arus dan tegangan terhadap laju produksi gas HHO. Hasil pengukuran seperti tampak pada tabel 4 . Pengukuran dilakukan dengan mengambil volum produksi gas konstan yaitu sebesar 50 $\mathrm{ml}$ sementara tegangan dan arusnya berubah selanjutnya diukur waktu yang dibutuhkan sehingga akan didapat laju produksi gas. Tampak semakin besar daya yang diberikan maka laju produksi gas semakin cepat.

\section{KESIMPULAN}

Berdasarkan hasil pengujian diperoleh kesimpulan sebagai berikut :

- Produksi gas HHO semakin meningkat dengan semakin tingginya konsentrasi $\mathrm{KOH}$

- Operasi elektroliser dapat menggunakan sumber DC menggunakan sel surya dimana produksi gas $\mathrm{HHO}$ akan ditentukan oleh kondisi radiasi matahi

- Pengujian menggunakan sumber DC dari power suplay tampak, semakin besar daya listrik yang diberikan maka semakin besar produksi gas $\mathrm{HHO}$ dihasilkan,

\section{DAFTAR PUSTAKA}

[1] Rizky Akbar Pratama dan Djoko SungkonoKawano, "Pengaruh Penggunaan Frekuensi Listrik terhadap Performa Generator HHO dan Unjuk Kerja Engine Honda Kharisma 125CC", JURNAL TEKNIK POMITS Vol. 2, No. 2, (2013) ISSN: $2337-3539$ (2301-9271 Print)

[2] Dody Wiryawan Denny Widhiyanuriyawan dan Nurkholis Hamidi, "Pengaruh Variasi Arus Listrik Terhadap Produksi Brown's Gas Pada 
Elektroliser", Jurnal Mahasiswa Fakultas Teknik Universitas Brawijaya

[3] Ihsan Sopandi, Yuli Hananto dan,Bayu Rudiyanto, "Studi Ketebalan Elektroda Pada Produksi Gas HHO (Hidrogen Hidrogen Oksigen) Oleh Generator Hho Tipe Basah Dengan Katalis NaHCO3 (Natrium Bikarbonat)", Rona Teknik Pertanian, 8(2)Oktober 2015

[4] Yanur Arzaqa Ğhiffari, dan D joko Sungkono Kawano, "Studi Karakteristik
Generator Gas HHO Tipe Dry Cell dan Wet Cell berdimensi $80 \times 80 \mathrm{~mm}$ dengan Penambahan PWM E-3 FF (1 kHz)", JURNAL TEKNIK POMITS Vol. 1, No. 1, (2013), hal. 1-6, ISSN: 2337-3539 (2301-9271 Print)

[5] Jackson, Frank. "Planning and Installing Photovoltaic Systems Second Edition". London : Earthscan, 2008. 